\title{
Ionic liquids in sample preparation
}

\author{
Rui Liu • Jing-fu Liu • Yong-guang Yin • Xia-lin Hu • \\ Gui-bin Jiang
}

Received: 30 May 2008 /Revised: 25 September 2008 / Accepted: 30 September 2008 / Published online: 29 October 2008

(C) Springer-Verlag 2008

\begin{abstract}
Due to their unique properties, their good extractabilities for various target analytes, and the fact that many compounds are highly soluble in them, room-temperature ionic liquids (ILs) are used as promising alternatives to the traditional organic solvents employed in sample preparation. ILs have been used as extraction solvents for a wide range of analytes, from environmental contaminates to biomacromolecules and nanomaterials, and as dissolution solvents for various detection techniques. In this paper, the main applications of ILs in sample preparation are reviewed, and the problems and challenges in this area are described.
\end{abstract}

Keywords Ionic liquids · Sample preparation ·

Environmental analysis $\cdot$ Bioanalysis $\cdot$ Nanomaterials

\section{Introduction}

Room-temperature ionic liquids (ILs) are a group of organic salts whose melting points range from $-81^{\circ} \mathrm{C}[1]$ to $125^{\circ} \mathrm{C}$ [2], which are far lower than other salts. The well-accepted definition of an IL is "any salt that has a melting point lower than ambient temperature," as stated by Welton [3]. Although the first IL was synthesized as early as the nineteenth century [4], it was over 100 years later that ILs began to attract the attention of scientists, specifically when Wilkes [5] reported the first room-temperature IL with the 1-alkyl-3-methylimidazolium cation, in 1982, and the same group reported the first air- and water-stable 1-ethyl-3-

R. Liu $\cdot$ J.-f. Liu $(\bowtie) \cdot$ Y.-g. Yin $\cdot$ X.-1. Hu $\cdot$ G.-b. Jiang

State Key Laboratory of Environmental Chemistry and

Ecotoxicology, Research Center for Eco-Environmental Sciences,

Chinese Academy of Sciences,

P.O. Box 2871, Beijing 100085, China

e-mail: jfliu@rcees.ac.cn methylimidazolium-based IL ten years latter [6]. Since then, hundreds of ILs have been synthesized and reported. In most cases, ILs have an asymmetrically substituted nitrogen-containing cation (e.g., imidazole, pyrrolidine, pyridine) and a halogen-based anion (e.g., $\mathrm{Cl}^{-}, \mathrm{Br}^{-}, \mathrm{I}^{-}$, $\left.\left[\mathrm{BF}_{4}\right]^{-},\left[\mathrm{AlCl}_{4}\right]^{-},\left[\mathrm{PF}_{6}\right]^{-}\right)$. Due to the insufficient stability and potential toxicity of ILs with halogen-contained anions, more and more ILs with low halogen contents or even halogen-free anions, such as bis(2-ethylhexyl)sulfosuccinate $[\mathrm{BEHSS}]^{-}$, trifluoroethanoate $\left[\mathrm{CF}_{3} \mathrm{CO}_{2}\right]^{-}$, acetate $\left[\mathrm{CH}_{3} \mathrm{CO}_{2}\right]^{-}$, bis[(trifluoromethyl)sulfonyl $]$imide $\left(\mathrm{Tf}_{2} \mathrm{~N}^{-}\right)$, and trifluoromethanesulfonate $\left(\mathrm{TfO}^{-}\right)$have been synthesized. Figure 1 shows the structures of some of the main IL cations and anions. Today, various ILs are available commercially.

Besides their low melting points, ILs have many other unique physicochemical properties, such as broad liquid ranges, negligible vapor pressures, good thermal stabilities, and good extractabilities for various organic compounds and metal ions [7]. By changing the combination of cation and anion, their miscibilities with water and organic solvents and the viscosities of ILs can be tuned. Thus, ILs are termed "designable solvents" [8], and various applications have reported for them. In analytical chemistry, ILs were used as stationary phases in gas chromatography [9-11], additives for capillary electrophoresis [12-15], matrices for MALDI [16-18], as well as solvents for spectral analysis [19-21] and electrochemistry [22]. Several reviews that focus on these topics have been published recently [23-27].

As the first and most tedious step in the whole process of analysis, sample preparation usually involves the separation and preconcentration of target analytes from complex matrixes, such as environmental samples and biological samples. Most sample preparation methods used in the laboratory are based on extraction, including Soxhlet 
<smiles>[R]n1cc[n+](CCCCCC)c1Nn1cccc1</smiles><smiles>[R][Y]([R])([Y])[R][P+]([R])([R])[R]</smiles>

Anions: ${ }^{\mathrm{F}}$<smiles>O=C1NN(S(=O)(=O)[O-])C(O)(OS(=O)(=O)O)O1</smiles><smiles>[3H]OS([13CH3])(=O)=O</smiles>
H

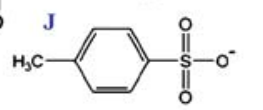

$$
\mathrm{Cl}^{-}, \mathrm{Br}^{-}, \mathrm{I}^{-},\left[\mathrm{BrF}_{4}\right]^{-},\left[\mathrm{PF}_{6}\right]^{-}
$$

Fig. 1 Schematic diagrams of the most commonly used ILs. Cations: $A$ : 1-alkyl-3-methylimidazolium $\left(\left[\mathrm{C}_{\mathrm{n}} \mathrm{MIM}\right]^{+}, \mathrm{C}_{\mathrm{n}}=\mathrm{n}\right.$-alkyl residues $\left.\mathrm{C}_{\mathrm{n}} \mathrm{H}_{2 \mathrm{n}+1}\right) ; B$ : 1-alkylpyridinium $\left(\left[\mathrm{C}_{\mathrm{n}} \mathrm{Py}\right]^{+}\right) ; \mathrm{C}:$ 1,1-dialkylpyrrolidinium $\left(\left[\mathrm{C}_{\mathrm{m}} \mathrm{C}_{\mathrm{n}} \mathrm{Pyr}\right]^{+}\right) ; D$ : tetraalkylammonium $\left(\left[\mathrm{N}_{4}\right]^{+}\right)$; E: tetraalkylphosphonium $\left(\left[\mathrm{P}_{4}\right]^{+}\right)$; Anions: $F$ : bis(trifluoromethanesulfonyl) amide $\left(\left[\mathrm{Tf}_{2} \mathrm{~N}\right]^{-}\right) ; G$ : trifluoromethanesulfonate $\left([\mathrm{TfO}]^{-}\right) ; H$ : dicyanimide $\left(\left[(\mathrm{CN})_{2} \mathrm{~N}\right]^{-}\right) ; I$ : alkylsulfates $\left(\left[\mathrm{C}_{\mathrm{n}} \mathrm{OSO}_{3}\right]^{-}\right)$. $J$ : tosylate ([OTos] $\left.]^{-}\right)$; other anions and commonly used alkyl chains are also shown

extraction, supercritical fluid extraction (SFE), subcritical water extraction (SWE), pressurized liquid extraction (PLE), microwave/sonication-assisted extraction (M/SAE), liquidliquid extraction (LLE), liquid-phase microextraction (LPME), membrane-separated liquid extraction (MSLE), solid-phase extraction (SPE), single-drop microextraction (SDME), solid-phase microextraction (SPME), stir bar sorptive extraction (SBSE), and membrane extraction with a sorbent interface (MESI). These methods have been summarized in a recent review given by Chen and coauthors [28]. Except for a few exceptions, such as SPE, SPME and SBSE, that are solvent-free, most sample preparation procedures are based on solvent extraction. Besides supercritical fluid and subcritical water, for a long time organic solvents were the only choice. These organic solvents are usually volatile or semivolatile at room temperature, combustible, and toxic to the operator to some extent. Since ILs can overcome most of these drawbacks, more and more applications of ILs in sample preparation have been reported.

Here, the applications of ILs to sample preparation (see Fig. 2 and Tables 1 and 2) and the extraction mechanisms of analytes with ILs (see Fig. 3) are reviewed. The problems and challenges that have arisen from the use of IL in sample preparation are also discussed.

\section{Extraction mechanisms}

\section{Partition mechanism}

Rogers and coauthors [2, 29] determined the partition coefficients between IL and water $\left(\mathrm{P}_{\mathrm{il}-\mathrm{w}}\right)$ of 19 different organic compounds, including six short-chained alcohols, phthalic acid with four derivatives, and benzene with six derivatives. They found that the $\log P_{\text {il-w }}$ and $\log K_{\text {ow }}$ of those compounds exhibited a good linear relation, and that the distribution coefficient was higher for the uncharged form than for the charged one. This is the first and best evidence for the partition mechanism.

The partitioning behaviors of 38 compounds in $\left[\mathrm{C}_{4} \mathrm{MIM}\right]\left[\mathrm{PF}_{6}\right] /$ water and octanol/water were further examined by Armstrong's group [30]. It was found that compounds containing acidic functional groups (e.g., carboxyl, phenolic hydroxyl) partitioned less to the IL phase than to octanol, while the reverse was true for aminegroup-bearing compounds, and the others (neutral molecules and ionizable compounds with both basic and acidic functions) exhibited similar distribution behaviors in both
Fig. 2 Schematic diagram of the main applications of ILs in sample preparation

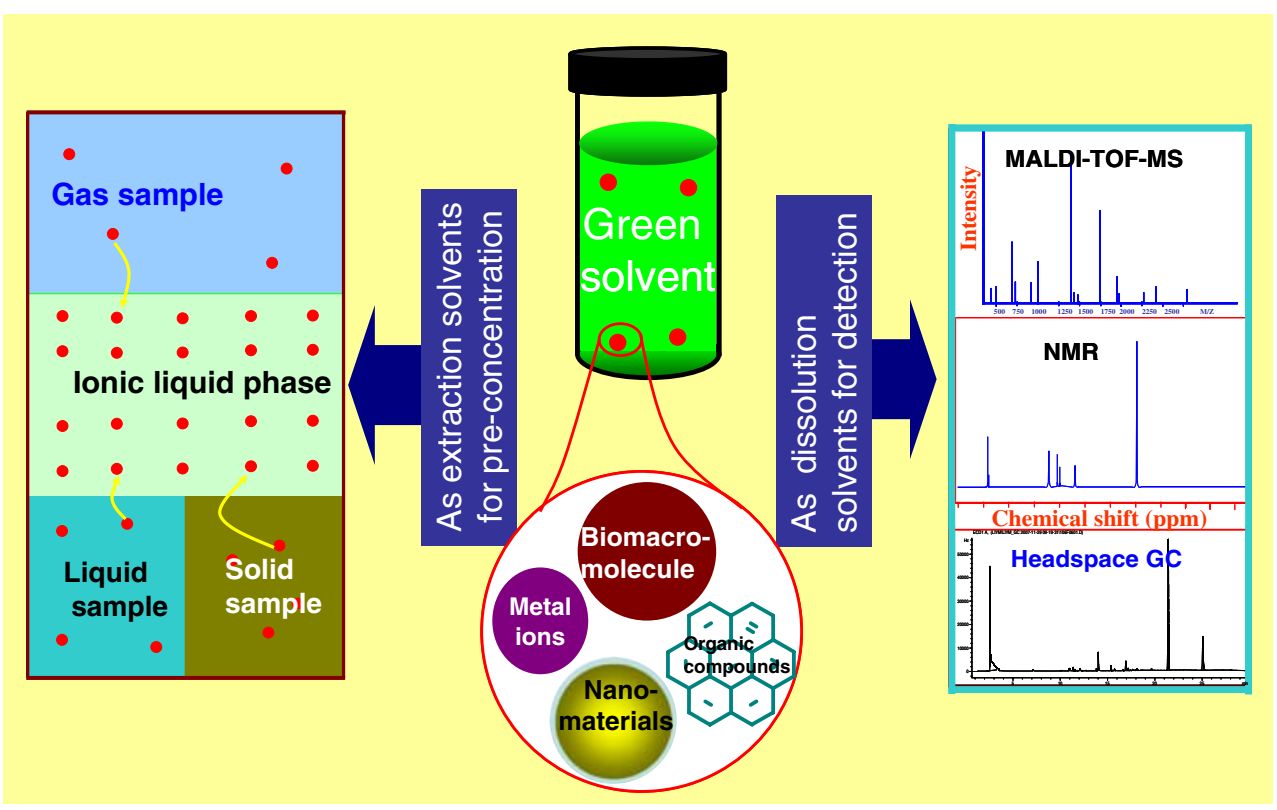


Table 1 Use of imidazolium-based ILs in sample preparation (as extractant)

\begin{tabular}{|c|c|c|c|c|c|}
\hline Ils & Analyte/sample(matrix) & Extraction mode & Analysis method & $\begin{array}{l}\text { Analytical } \\
\text { performance }\end{array}$ & Reference \\
\hline$\left[\mathrm{C}_{8} \mathrm{MIM}\right]\left[\mathrm{PF}_{6}\right]$ & PAHs/water & $\begin{array}{l}\text { Headspace SDME, immersed } \\
\text { SDME }\end{array}$ & HPLC-FLD & $\begin{array}{l}\mathrm{EF}=42-166 ; \\
\mathrm{RSD}=2.8-12 \%\end{array}$ & {$[38]$} \\
\hline$\left[\mathrm{C}_{4} \mathrm{MIM}\right]\left[\mathrm{PF}_{6}\right]$ & Chlorobenzenes/water & Headspace SDME & HPLC-VWD & $\begin{array}{l}\mathrm{LOD}=0.102- \\
0.203 \mu \mathrm{g} / 1 \\
\mathrm{RSD}=1.6-5.1 \%\end{array}$ & [39] \\
\hline$\left[\mathrm{C}_{4} \mathrm{MIM}\right]\left[\mathrm{PF}_{6}\right]$ & Phenols/water & Headspace SDME & HPLC-VWD & $\begin{array}{l}\mathrm{EF}=17.2-160.7 \\
\mathrm{RSD}=5.4-8.9 \% \\
\mathrm{LOD}=0.3-0.5 \mu \mathrm{g} / \mathrm{L}\end{array}$ & {$[40]$} \\
\hline$\left[\mathrm{C}_{6} \mathrm{MIM}\right]\left[\mathrm{PF}_{6}\right]$ & $\begin{array}{l}\text { 4-Nonylphenol and } \\
\text { 4-tert-octylphenol /water }\end{array}$ & LPME & HPLC-VWD & $\begin{array}{l}\mathrm{EF}=163,130 ; \\
\mathrm{LOD}=0.3,0.7 \mu \mathrm{g} / 1 ; \\
\mathrm{RSD}=7.8 \%, 3.2 \%\end{array}$ & [41] \\
\hline$\left[\mathrm{C}_{4} \mathrm{MIM}\right]\left[\mathrm{PF}_{6}\right]$ & $\begin{array}{l}\text { Dichlorodiphenyltrichloroethane } \\
\text { and its metabolites/water }\end{array}$ & Headspace SDME or LPME & HPLC-VP & $\begin{aligned} \mathrm{LOD} & =0.05-0.08 \mu \mathrm{g} / 1 \\
\mathrm{RSD} & =6.8-8 \%\end{aligned}$ & {$[42]$} \\
\hline$\left[\mathrm{C}_{4} \mathrm{MIM}\right]\left[\mathrm{PF}_{6}\right]$ & Chlorinated anilines/water & $\begin{array}{l}\text { Headspace SDME, high } \\
\text { temperature }\end{array}$ & HPLC-VP & $\begin{array}{l}\mathrm{LOD}=0.5-1.0 \mu \mathrm{g} / 1 \\
\mathrm{RSD}=5-7 \%\end{array}$ & [44] \\
\hline$\left[\mathrm{C}_{8} \mathrm{MIM}\right]\left[\mathrm{PF}_{6}\right]$ & BETXs/paint & SPME & GC-FID & $\begin{aligned} \mathrm{LOD} & =0.1-0.8 \mu \mathrm{g} / \mathrm{ml} \\
\mathrm{RSD} & =3.5-10 \%\end{aligned}$ & [48] \\
\hline$\left[\mathrm{C}_{8} \mathrm{MIM}\right][\mathrm{TfO}]$ & PAHs/water & $\begin{array}{l}\text { Nafion membrane-supported } \\
\text { ILs SPME }\end{array}$ & GC-MS & $\begin{array}{l}\mathrm{LOD}=4-5 \mu \mathrm{g} / \mathrm{ml} \\
\mathrm{RSD}=3.5-10 \%\end{array}$ & [49] \\
\hline$\left(\left[\mathrm{C}_{12} \mathrm{MIM}\right] \mathrm{Br}\right.$ & Phthalates/water & $\begin{array}{l}\text { IL mixed hemimicelle-based } \\
\text { SPE }\end{array}$ & HPLC-UV & $\begin{array}{l}\mathrm{EF}=600 \text { or higher; } \\
\mathrm{LOD}=0.12-0.17 \mu \mathrm{g} / 1\end{array}$ & {$[50]$} \\
\hline$\left[\mathrm{C}_{4} \mathrm{MIM}\right]\left[\mathrm{PF}_{6}\right]$ & PAHs/river water & $\begin{array}{l}\text { Semipermeable membrane } \\
\text { device-based extraction }\end{array}$ & HPLC-FLD & $\mathrm{EF}=830-7800$ & {$[53]$} \\
\hline$\left[\mathrm{C}_{4} \mathrm{MIM}\right]\left[\mathrm{PF}_{6}\right]$ & $\begin{array}{l}\text { Dichloromethane, } \mathrm{p} \text {-xylene, } \\
\text { and n-undecane/water }\end{array}$ & SDME & GC-MS & $\begin{array}{c}\mathrm{LOD}=5.6-15.6 \mathrm{ng} / \mathrm{ml} \\
\mathrm{RSD}=3.3-4.4 \%\end{array}$ & {$[51]$} \\
\hline$\left[\mathrm{C}_{4} \mathrm{tmsim}\right]\left[\mathrm{PF}_{6}\right]$ & $\mathrm{Al}^{3+} /$ dialysis concentrates & $\begin{array}{l}\text { 3,5-Ditertbutylsalicylfluorone } \\
\text { as carrier, LLE }\end{array}$ & Spectrophotometer & $\mathrm{LOD}=0.06 \mu \mathrm{g} / 1$ & {$[66]$} \\
\hline$\left[\mathrm{C}_{8} \mathrm{MIM}\right]\left[\mathrm{PF}_{6}\right]$ & $\mathrm{Pb}^{2+} /$ water & Dithizone as carrier, LLE & GFAAS & $\begin{array}{l}\mathrm{EF}=200 \\
\mathrm{LOD}=0.1 \mathrm{mg} / 1 .\end{array}$ & {$[64]$} \\
\hline$\left[\mathrm{C}_{4} \mathrm{tmsim}\right]\left[\mathrm{PF}_{6}\right]$ & $\mathrm{Hg}^{2+} /$ water & $\begin{array}{l}o \text {-Carboxyphenyldia-zoamino- } \\
p \text {-azobenzene as carrier, LLE }\end{array}$ & Cold vapor AAS & $\mathrm{LOD}=0.01 \mathrm{ng} / \mathrm{ml}$ & {$[65]$} \\
\hline$\left[\mathrm{C}_{6} \mathrm{MIM}\right]\left[\mathrm{PF}_{6}\right]$ & Benzophenone-3/human urine & SDME & HPLC-DAD & $\begin{aligned} \mathrm{LOD} & =1.3 \mathrm{ng} / \mathrm{ml} \\
\mathrm{RSD} & =6 \%\end{aligned}$ & {$[72]$} \\
\hline$\left[\mathrm{C}_{4} \mathrm{MIM}\right] \mathrm{Cl}$ & $\begin{array}{l}\text { Testosterone and } \\
\text { epitestosterone/human urine }\end{array}$ & $\begin{array}{l}\text { Aqueous two-phase system } \\
\text { extraction }\end{array}$ & HPLC-UVD & $\begin{array}{l}\mathrm{LOD}=1 \mathrm{ng} / \mathrm{ml} \\
\mathrm{RSD}=1.5-5.5 \%\end{array}$ & [73] \\
\hline $\begin{array}{c}{[\mathrm{CnMIM}]\left[\mathrm{PF}_{6}\right]} \\
{[\mathrm{CnMIM}]\left[\mathrm{BF}_{4}\right]}\end{array}$ & Acetone/human plasma & Headspace SPME & $\begin{array}{l}\text { Cataluminescence } \\
\text { (CTL) sensor }\end{array}$ & $\begin{array}{l}\mathrm{EF}=80, \mathrm{RSD}=3.3 \%- \\
7.6 \%\end{array}$ & {$[75]$} \\
\hline$\left[\mathrm{C}_{4} \mathrm{MIM}\right] \mathrm{Cl}$ & $\begin{array}{l}\text { Opium alkaloids/ Pericarpium- } \\
\text { papaveris }\end{array}$ & $\begin{array}{l}\text { Aqueous two-phase systems } \\
\text { extraction }\end{array}$ & HPLC-UV & $\begin{array}{c}\mathrm{LOD}=0.02-0.03 \\
\mu \mathrm{g} / \mathrm{ml} ; \mathrm{RSD}= \\
2.1 \%-3.8 \%\end{array}$ & {$[76]$} \\
\hline$\left[\mathrm{C}_{8} \mathrm{MIM}\right]\left[\mathrm{PF}_{6}\right]$ & $\begin{array}{l}\text { Formaldehyde/shiitake } \\
\text { mushroom }\end{array}$ & $\begin{array}{l}\text { 2,4-Dinitrophenylhydrazine } \\
\text { (DNPH) as derivative, LPME }\end{array}$ & HPLC-UV & $\begin{array}{r}\mathrm{LOD}=5 \mu \mathrm{g} / 1 \\
\mathrm{RSD}=3.5 \%\end{array}$ & [77] \\
\hline$\left[\mathrm{C}_{4} \mathrm{MIM}\right]\left[\mathrm{PF}_{6}\right]$ & Ds-DNA/water & Liquid-liquid extraction & $\begin{array}{r}\text { Luminescence } \\
\text { spectrometer }\end{array}$ & & [122] \\
\hline$\left[\mathrm{C}_{4} \mathrm{MIM}\right] \mathrm{Cl}$ & Protein/biological fluid & $\begin{array}{l}\text { Aqueous two-phase system } \\
\text { extraction }\end{array}$ & Bradford method & $E F=20$ & [92] \\
\hline
\end{tabular}

$S D M E$, single-drop microextraction; HF-SILM, hollow-fiber-supported IL membrane; $E F$, enrichment factor; $L O D$, limit of detection

systems. This can probably be attributed to the lower basicity of ILs compared to octanol.

Data on the partition coefficients between ILs and water are very limited, not only in terms of the analytes tested but also with regard to the number of ILs investigated. Nevertheless, the partitioning mechanism is one of the most important mechanisms for understanding the separation and enrichment of analytes from the aqueous phase to the IL phase, such as occurs in the extraction of PAHs, phenols, BETXs, chlorobenzene, chlorinated anilines, and chlorophenols from water for further analysis. Another notable point about the partitioning of organic compounds between water 
Table 2 Structures and applications of some non-imidazolium-based ILs

\begin{tabular}{|c|c|c|c|}
\hline Structure of ILs & Comment & Physical state and function & Reference \\
\hline & $\begin{array}{l}\text { Disulfide function group } \\
\text { containing }\end{array}$ & \multirow[t]{3}{*}{$\begin{array}{l}\text { Liquid, } \\
\text { Task-specific ILs for } \mathrm{Hg}^{2+}, \mathrm{Cd}^{2+}\end{array}$} & \multirow[t]{3}{*}{67,68} \\
\hline & $\begin{array}{l}\text { Thiourea function group } \\
\text { containing }\end{array}$ & & \\
\hline L & $\begin{array}{l}\text { Urea function group } \\
\text { containing }\end{array}$ & & \\
\hline$\left[\mathrm{Bu} \mathrm{O}_{\mathrm{Bu}}^{\prime} \mathrm{O}^{\top} \mathrm{F}\right.$ & $\begin{array}{l}\text { Phosphoryl function } \\
\text { groups containing }\end{array}$ & $\begin{array}{l}\text { Task-specific ILs for } \\
\mathrm{UO}_{2}{ }^{2+} \text { extraction }\end{array}$ & 71 \\
\hline & & $\begin{array}{l}\text { Task-specific ILs for } \mathrm{Pd}^{2+} \text {, } \\
\mathrm{Cu}^{2+}, \mathrm{Hg}^{2+}, \mathrm{Ag}^{+} \text {extraction }\end{array}$ & 70 \\
\hline & $\mathrm{X}=\mathrm{Tf}_{2} \mathrm{~N}^{-}, \mathrm{PF}_{6}^{-}$ & $\begin{array}{l}\text { Liquid, } \quad \text { water-immiscible. } \\
\text { Task-specific ILs for } \mathrm{Am}^{3+} \text { Extraction }\end{array}$ & 69 \\
\hline & $\begin{array}{l}\mathrm{X}^{+}=\text {Ammonium, } \\
\text { Alkyl-ammonium, }\end{array}$ & $\begin{array}{l}\text { Solid or liquid } \\
\text { As matrix for MALDI-MS }\end{array}$ & 106 \\
\hline & $\begin{array}{l}\text { Methyl-imidazolium } \\
\text { Pyridinium }\end{array}$ & & \\
\hline & $\begin{array}{l}{\left[\mathrm{C}_{\mathrm{n}} \mathrm{OHMIM}\right]\left[\mathrm{Tf}_{2} \mathrm{~N}\right]} \\
\mathrm{n}=2,3,6,8\end{array}$ & $\begin{array}{l}\text { NA } \\
\text { Extract protein such as cytochrome } c\end{array}$ & 94,95 \\
\hline & {$\left[\mathrm{C}_{1} \mathrm{OC}_{1} \mathrm{MIM}\right]\left[\mathrm{Tf}_{2} \mathrm{~N}\right]$} & $\begin{array}{l}\text { from aqueous phase mediated by } \\
\text { crown-ether }\end{array}$ & \\
\hline & {$\left[\mathrm{C}_{3} \mathrm{UC} \mathrm{C}_{4} \mathrm{MIM}\right]\left[\mathrm{Tf}_{2} \mathrm{~N}\right]$} & & \\
\hline & {$[18 \mathrm{C} 6 \mathrm{MIM}]\left[\mathrm{PF}_{6}\right]$} & $\begin{array}{l}\text { NA, } \\
\text { Task-specific ILs for protein extraction }\end{array}$ & 96 \\
\hline
\end{tabular}


Table 2 (continued)

\begin{tabular}{|c|c|c|c|}
\hline 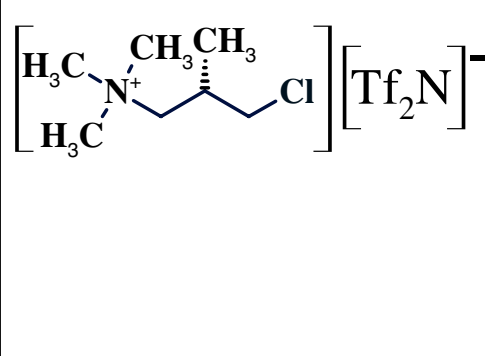 & $\begin{array}{l}(R)-\quad \text { and } \\
(S)-[\mathrm{CHTA}]^{+}\left[\mathrm{Tf}_{2} \mathrm{~N}\right]^{-}\end{array}$ & $\begin{array}{l}\text { Liquid, } \\
\text { Functions as both solvent and chiral } \\
\text { selector for the determination of } \\
\text { enantiomeric compositions of } \\
\text { pharmaceutical products }\end{array}$ & 126,127 \\
\hline
\end{tabular}

and ILs is the pH dependence of ionizable compounds. This property enables us to adjust the $\mathrm{pH}$ values of different phases to achieve extraction and back-extraction of the target analytes, which has been utilized in three-phase extraction.

It is generally believed that the transfer of analytes from the aqueous phase to the IL phase by this partitioning mechanism is similar to that which occurs in traditional organic solvents.

\section{Ion-exchange mechanism}

While the partitioning mechanism plays a significant role in the extraction of organic compounds from the aqueous to the IL phase, it seems that the transfer of metal ions to IL is based on a different mechanism. Dai et al. [31] reported the first example of extracting metal ion $\left(\mathrm{Sr}^{2+}\right)$ from $\mathrm{NO}_{3}{ }^{-}$

Fig. 3 Schematic diagram of IL-based extraction modes: A immersed and headspace liquid phase microextraction; B solid-phase microextraction based on IL coating;

C headspace-support solid sample loading; D temperaturecontrolled IL dispersive liquid phase microextraction;

E) IL/aqueous two-phase system extraction
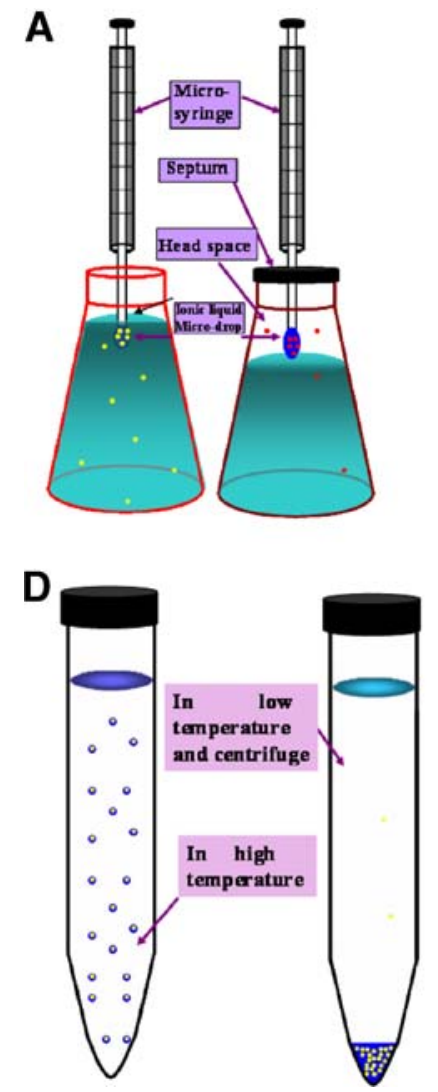

containing water to methylimidazolium bis [(trifluoromethyl) sulfonyl]amide $\left(\left[\mathrm{R}_{1} \mathrm{R}_{2} \mathrm{MIM}\right]\left[\mathrm{Tf}_{2} \mathrm{~N}\right]\right)$ and methylimidazolium hexafluorophosphate $\left(\left[\mathrm{R}_{1} \mathrm{R}_{2} \mathrm{MIM}\right]\left[\mathrm{PF}_{6}\right]\right)$ (where $\mathrm{R}_{1}=$ ethyl, propyl, or butyl, and $\mathrm{R}_{2}=\mathrm{H}$, or methyl) using crown ether (CE) dicyclohexyl-18-crown-6 as the chelating agent. In the presence of dicyclohexyl-18-crown6 , the distribution coefficient of metal ion between ILs and water increased from less than 1 to between 4.2 and 11000 . Dietz et al. [32] argued that the possible extraction mechanism is cation exchange:

$\mathrm{Sr} \cdot \mathrm{CE}^{2+}+2 \mathrm{C}_{n} \mathrm{MIM}_{\text {org }}^{+} \Leftrightarrow \mathrm{Sr} \cdot \mathrm{CE}_{\text {org }}^{2+}+2 \mathrm{C}_{n} \mathrm{MIM}^{+}$

The same mechanism was used to explain the good extraction abilities of hydrophobic ILs $\left(\left[\mathrm{C}_{n} \mathrm{MIM}\right]\left[\mathrm{PF}_{6}\right]\right.$ and
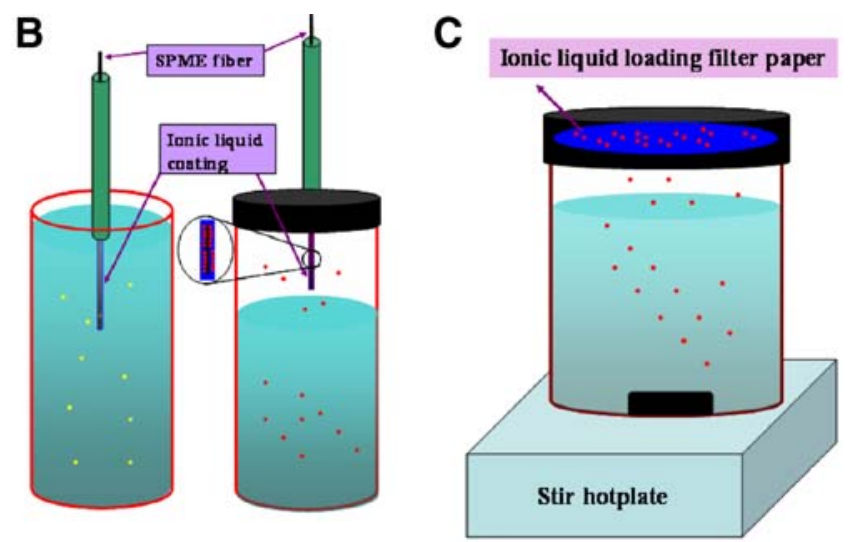

E

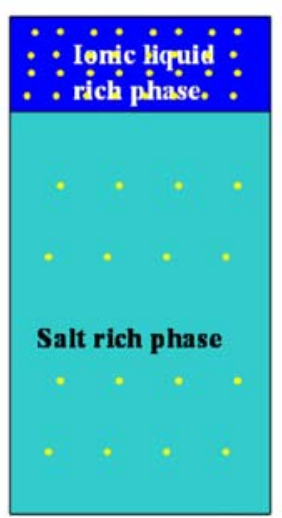

\section{Analyte}

Volatile analyte or semi-volatile analyte 
$\left.\left[\mathrm{C}_{\mathrm{n}} \mathrm{MIM}\right]\left[\mathrm{Tf}_{2} \mathrm{~N}\right]\right)$ for $\mathrm{UO}^{2+}$ with the help of CMPO, which played the same role as dicyclohexyl-18-crown-6 [33]:

$$
\begin{gathered}
\mathrm{UO}_{2(\mathrm{aq})}^{2+}+\left[\mathrm{C}_{n} \mathrm{MIM}\right]_{\mathrm{IL}}^{+}+\mathrm{NO}_{3(\mathrm{aq})}^{-}+\mathrm{L}_{\mathrm{IL}} \\
\left.\Leftrightarrow\left[\left(\mathrm{UO}_{2}\right) \mathrm{NO}_{3}\right] \mathrm{L}\right]_{\mathrm{IL}}^{+}+\left[\mathrm{C}_{n} \mathrm{MIM}\right]_{\mathrm{aq}}^{+}
\end{gathered}
$$

This mechanism was further supported by the results of a coordination environment study using extended X-ray absorption fine structure (EXAFS) [34].

Sometimes anion exchange may be the main driving force for the transfer of metal ion into ILs. By using methods such as equilibrium thermodynamics, optical absorption, luminescence spectroscopy, high-energy X-ray scattering, EXAFS, and molecular dynamics simulations, Jensen demonstrated that for the extraction of lanthanide $\left(\mathrm{Ln}^{3+}\right)$ to $\left[\mathrm{C}_{4} \mathrm{MIM}\right]\left[\mathrm{Tf}_{2} \mathrm{~N}\right]$ with 1-(2-thienyl)-4,4,4-trifluoro-1,3-butanedione (HTTA) as chelating agent, the mechanism was anion exchange rather than cation exchange [35]:

$$
\begin{aligned}
& \mathrm{Ln}^{3+}+4 \mathrm{HTTA}_{\text {org }}+\left[\mathrm{C}_{4} \mathrm{MIM}\right]^{+}\left[\mathrm{Tf}_{2} \mathrm{~N}^{-}\right]_{\text {org }} \\
& \quad \Leftrightarrow\left[\mathrm{C}_{4} \mathrm{MIM}^{+}\right]\left[\operatorname{Ln}(\mathrm{TTA})_{4}^{-}\right]_{\text {org }}+4 \mathrm{H}^{+}+\mathrm{Tf}_{2} \mathrm{~N}^{-}
\end{aligned}
$$

Another study inferred that anion exchange also plays an important role in the extraction of organic compounds such as dyes from aqueous phases to ILs, with or without the presence of crown ether [36]. These mechanisms have been reviewed by Cocalia et al. [37].

Both the partition and ion-exchange mechanisms play important roles in the extraction process. The organic compounds tend to be extracted by the partitioning mechanism, while ion exchange may contribute more to the extraction of metal ions. These two mechanisms may sometimes cooperate with each other.

\section{Use of ILs as extraction solvents}

\section{Extraction of organic contaminants}

Our group [38] provided the first example of the use of ILs as solvents for liquid-phase microextraction (LPME) of polycyclic aromatic hydrocarbons (PAHs) from water. A $3 \mu \mathrm{l}$ drop of $\left[\mathrm{C}_{8} \mathrm{MIM}\right]\left[\mathrm{PF}_{6}\right]$ suspended on the tip of a microsyringe was employed for immersed or headspace extraction of the analytes from water samples for $30 \mathrm{~min}$, followed by direct injection into the liquid chromatography system for determination. The enrichment factor ranged from 42 to 166 , which is about three times that obtained by 1-octanol. Using a similar protocol, chlorobenzenes [39], phenols [40, 41], dichlorodiphenyltrichloroethane and its metabolites [42] in a water sample were preconcentrated and analyzed. A later study showed that many organic pollutants, including BTEX (benzene, toluene, ethylbenzene, and xylene), PAHs, phthalates, phenols, aromatic amines, herbicides, organotin compounds, and organomecury compounds can be preconcentrated by this method [43].

Since they are a group of thermally stable and nonvolatile liquids, ILs are very suitable for high-temperature headspace single-drop microextraction (HS-SDME) of volatile and semivolatile compounds. Peng et al. [44] used this strategy to extract four anilines in environmental water samples at temperatures as high as $90{ }^{\circ} \mathrm{C}$. The high temperature enhanced the volatilization of analytes into the head space and thus improved the enrichment factor.

Recently, Zhou et al. [45] developed a temperaturecontrolled IL dispersive liquid phase microextraction technique for extracting pyrethroid pesticides in water samples. A homogeneous phase of IL and water was obtained by heating, while cooling of the homogeneous liquid mixture produced phase separation due to the decreased solubility, i.e., so-called "upper critical separation temperature (UCST)" behavior. Briefly, $45 \mu 1$ of [ $\left.\mathrm{C}_{6} \mathrm{MIM}\right]$ $\left[\mathrm{PF}_{6}\right]$ was added to about $10 \mathrm{ml}$ of a water sample, and this was then heated to $70{ }^{\circ} \mathrm{C}$, which enabled the IL to completely dissolve in water. After the extraction, the system was cooled down and phase separation of IL from water was realized by centrifuge. The analyte containing IL was then diluted for HPLC analysis. Some amino-acidbased ILs [46] such as [ $\left.\mathrm{P}_{4444}\right]$ [Tf-Leu] [47] that have lower critical solution temperatures (LCSTs) have the potential for use in sample preparation.

Compared to SDME, SPME and SPE have the advantages of robustness and larger surface-to-volume ratios. A disposable IL-coated headspace SPME fiber was created in order to determine BETXs in paints by Liu et al. [48]. This SPME fiber has some advantages over commercial SPME fibers, including a much lower cost per fiber, comparable reproducibility (RSD $<11 \%$ ), and elimination of carryover effects. This method was later improved by Hsieh et al. [49] in order to determine trace PAHs in water sample. Nafion was coated onto the fiber prior to the IL coating, which enhanced the amount and stability of the IL film adsorbed onto the fiber. Recently, Li et al. [50] used silica coated with $\left[\mathrm{C}_{n} \mathrm{MIM}\right] \mathrm{Br}(n=8,12)$ as a sorbent for the solid-phase extraction of phthalates in environmental water samples. Five target analytes were quantitatively extracted with enrichment factors as high as 600 .

The negligible volatility of IL prohibited the direct coupling of IL-based LPME with GC. This is because the injection of ILs into GC could contaminate the GC column. However, this obstacle was overcome recently with the development of a removable interface that permits the direct injection of the ILs into the GC [51]. The core part of 
the interface is a cotton-containing tube that enables the retention of ILs but not the analytes when maintained at $140{ }^{\circ} \mathrm{C}$. Using this interface, dichloromethane, $p$-xylene, and $n$-undecane were determined by coupling single-drop microextraction, with $\left[\mathrm{C}_{4} \mathrm{MIM}\right]\left[\mathrm{PF}_{6}\right]$ used as extraction solvent, to GC/MS. One remarkable advantage of this technique is that solvent delay is no longer required, so polar compounds with short retention times can be recorded and quantitatively determined.

Although ILs are widely used in liquid sample preparation, their application in solid matrix samples has been limited, partly due to their high viscosities. Khodaoust et al. [52] assessed the extraction performances of ILs for organic contaminants (DDT, dieldrin, hexachlorobenzene and pentachlorophenol) in soil. It was found that the extraction of these compounds (except DDT) from organic-matter-free soil (montmorillonite) with $\left[\mathrm{C}_{4} \mathrm{MIM}\right]\left[\mathrm{PF}_{6}\right](79-92 \%)$ was nearly as effective as extraction with acetone and ethanol (85-100\%), whereas extraction from glacial till with ILs was less effective (15-61\%) than with organic solvents (59-100\%). It was also found that the performance of the hydrophilic IL $\left[\mathrm{C}_{4} \mathrm{MIM}\right] \mathrm{Cl}$ was worse than that of the hydrophobic IL $\left[\mathrm{C}_{4} \mathrm{MIM}\right]\left[\mathrm{PF}_{6}\right]$. These preliminary results indicated that hydrophobic ILs may be alternatives to traditional solvents for the extraction of organic pollutants from soils with low organic matter.

Passive sampling is attracting more and more attention due to its great importance in environmental monitoring and environmental risk assessment. Zhao et al. [53] developed an IL-containing semipermeable membrane device (IL-SPMDs) to monitor PAHs in water. The results agreed well with those obtained with the traditional triolein SPMD, suggesting that IL-SPMD is a viable alternative for passive sampling in the field. The main concern may be the relatively high water solubility of ILs compared to triolein.

\section{Extraction of metal contaminants}

Extractions of metal ions from aqueous phases to ILs have been extensively investigated, including those of $\mathrm{Sr}^{2+}[31$, $32,34,54,55]$, alkali and alkali earth cations [56-58], rare earth elements $[59,60]$ and other heavy metal ions, such as $\mathrm{Pd}^{2+}, \mathrm{Cu}^{2+}, \mathrm{Pb}^{2+}, \mathrm{Zn}^{2+}, \mathrm{Cd}^{2+}, \mathrm{Hg}^{2+}$, and $\mathrm{Ag}^{+}$[61-63]. Their high performance encouraged researchers to test the applicability of ILs to the preconcentration of metal ions in environmental samples.

Recently, Li et al. [64-66] reported that, with the help of dithizone, o-carboxyphenyldiazoamino- $p$-azobenzene (CDAA), and 3,5-ditertbutylsalicylfluorone (DTBSF), trace lead and mercury in water samples and aluminum in dialysis can be extracted into $\left[\mathrm{C}_{8} \mathrm{MIM}\right]\left[\mathrm{PF}_{6}\right]$ and 1butyl-3-trimethylsilylimidazolium hexafluorophosphate $\left(\left[\mathrm{C}_{4}\right.\right.$ tmsim $\left.]\left[\mathrm{PF}_{6}\right]\right)$, respectively.
As described in the early part of this review, metal ions are usually extracted into ILs with a complexing reagent, which makes the selective extraction of a specific metal ion possible. However, this increases the complexity of this process to some extent. Worse still, the reagents are difficult to remove from the ILs. This problem can be solved by derivatizing the cation or anion of ILs with disulfide, urea, thiourea, thioether, phosphoryl groups or other functional groups in order to synthesize task-specific ILs. $\mathrm{Hg}^{2+}$, $\mathrm{Cd}^{2+}[67,68], \mathrm{Am}^{3+}[69], \mathrm{Pd}^{2+}, \mathrm{Cu}^{2+}, \mathrm{Hg}^{2+}, \mathrm{Ag}^{+}[62]$, and $\mathrm{U}^{6+}[70]$ were successfully extracted from the aqueous phase into task-specific ILs, or a mixture of the task-specific ILs and a less expensive conventional IL.

Recently, it was reported that $\mathrm{Hg}^{2+}$ can be extracted into $\left[\mathrm{C}_{n} \mathrm{MIM}\right]\left[\mathrm{PF}_{6}\right](n=4,6,8)$ without the need for any complexing reagent [71]. Heating the ILs to a moderate temperature $\left(60{ }^{\circ} \mathrm{C}\right.$ for $\left.\left[\mathrm{C}_{8} \mathrm{MIM}\right]\left[\mathrm{PF}_{6}\right]\right)$ accelerates the extraction process, and up to $90-100 \%$ of $\mathrm{HgCl}_{2}$ in $0.15 \mathrm{M}$ acetate buffer $(\mathrm{pH} 4.68)$ can be transferred into ILs over timescales ranging from several hours to $100 \mathrm{~h}$. This challenges our previous knowledge that the partition coefficient of a metal ion between a non-task-specific IL and water is usually less than 1. For example, the distribution ratios of $\mathrm{Hg}^{2+}$ and $\mathrm{Cd}^{2+}$ between $\left[\mathrm{C}_{4} \mathrm{MIM}\right]\left[\mathrm{PF}_{6}\right]$ and an aqueous phase at $\mathrm{pH} 7$ were 0.84 and 0.03 , respectively [67].

\section{Preparation of biosamples}

The analysis of body fluids such as urine and blood is a great challenge due to their complex matrices. However, the use of ILs in sample preparation may solve this problem to some extent. As an example, benzophenone-3 (BZ3), a compound (commonly used as UV filter in cosmetic products) that can be absorbed through the skin into the human body was determined in urine samples using $\left[\mathrm{C}_{6} \mathrm{MIM}\right]\left[\mathrm{PF}_{6}\right]$-based single-drop microextraction [72]. The abuse of drugs such as stimulants and anabolic androgenic steroids (AAS) among athletes is not only a threat to fair sports competitions, but also a threat to the health of the athletes abusing them. Successful control over the use of these compounds lies in the ability to determine these compounds in bodily fluids. Coupling an aqueous two-phase system (ATPS) consisting of $\left[\mathrm{C}_{4} \mathrm{MIM}\right] \mathrm{Cl}$ and $\mathrm{K}_{2} \mathrm{HPO}_{4}$ with reversed-phase high-performance liquid chromatography (RP-HPLC), He et al. [73] analyzed testosterone (T) and epitestosterone (ET) in human urine simultaneously. ILs were also adopted for the liquid-liquid extraction of amphetamine $(\mathrm{C} 9 \mathrm{~N})$ and nikethamide $(\mathrm{C} 10 \mathrm{~N})$ from the aqueous phase, and it was found that some ILs, such as $\left[\mathrm{C}_{2} \mathrm{MIM}\right][\mathrm{OAc}]$, exhibited better extraction performance than traditional solvents. The above results were consistent with the predictions made by the COSMO-RS 
(conductor-like screening model for real solvents) model [74], and they imply that IL-based extraction is a promising sample preparation method for drug analysis.

Yang and coauthors [75] coupled a cataluminescence (CTL) sensor with IL ([BMIM] $\left[\mathrm{CO}_{2} \mathrm{CF}_{3}\right]$ )-based headspace solid-phase microextraction (HS-SPME) for the quantification of human plasma acetone levels associated with diabetic disease. Taking the advantage of its unique properties, such as its nonvolatile and nonflammable nature and high thermal stability, the IL was conveniently adopted as a pseudo-solid carrier for the direct loading of acetone into a CTL sensor without matrix interference. Acetone from diabetic patient plasma and plasma samples spiked with acetone along with methanol, ethanol, and formaldehyde was conveniently and rapidly extracted and enriched in $3 \mu \mathrm{l}$ of the IL and then rapidly quantified by the CTL sensor. As the IL is distributed on a filter paper with a large mass transfer area, an enrichment factor of 80 (six times higher than that of HSSDME-CTL) was realized within $5 \mathrm{~min}$.

Besides bodily fluids, the analysis of compounds in other biological samples is also very important. The analysis of the opium alkaloid contents of opium poppies is important for legal and intelligence purposes. An ILbased aqueous two-phase system $\left(\left[\mathrm{C}_{4} \mathrm{MIM}\right] \mathrm{Cl}\right.$ and $\mathrm{K}_{2} \mathrm{HPO}_{4}$ buffer) was introduced as a simple, rapid and effective sample pretreatment technique for high-performance liquid chromatography (HPLC) analysis of the major opium alkaloids (codeine and papaverine) in Pericarpium papaveris [76]. Formaldehyde in shiitake mushroom was also determined by coupling IL-based LPME with HPLC [77]. The formaldehyde in the mushroom was leached into water, derivated by 2,4-dinitrophenylhydrazine (DNPH), and extracted into a $10 \mu \mathrm{l}$ drop of $\left[\mathrm{C}_{8} \mathrm{MIM}\right]\left[\mathrm{PF}_{6}\right]$ by the LPME procedure. In these two examples, the analytes were first leached from solid samples into water and then extracted with ILs. Insecticidal and microbicidal extracts from the fungus Cantharellus cibarius were directed extracted into a series of ILs [78], indicating that ILs can be used in direct extraction from solid samples.

\section{Extraction of compounds of biological importance}

ILs have also been employed to extract antibiotics and amino acids from aqueous phases. Erythromycin $\mathrm{A}$ in the aqueous phase was extracted into $\left[\mathrm{C}_{4} \mathrm{MIM}\right]\left[\mathrm{PF}_{6}\right][79]$, and penicillin $\mathrm{G}$ was extracted by the ILs $\left[\mathrm{C}_{n} \mathrm{MIM}\right]\left[\mathrm{PF}_{6}\right], n=4$, 6,8 and $\left[\left(\mathrm{C}_{8}\right)_{3} \mathrm{C}_{1} \mathrm{~N}\right] \mathrm{Cl}$ (TOMAC) with direct solvent extraction and in supported liquid membrane extraction mode, respectively [80]. As they are a group of emerging contaminates [81-84], the analysis of antibiotics in environmental and biological samples is becoming more and more important, and ILs may play a positive role in sample preparation for the analysis of these compounds.
Amino acids are another group of compounds of great biological importance. In the presence of dicyclohexano18-crown-6, four amino acids (Trp, Gly, Ala, Leu) were extracted into $\left[\mathrm{C}_{4} \mathrm{MIM}\right]\left[\mathrm{PF}_{6}\right]$ [85]. L-Tryptophan from fermentation broth was selectively extracted by various ILs, including $\left[\mathrm{C}_{6} \mathrm{MIM}\right]\left[\mathrm{BF}_{4}\right],\left[\mathrm{C}_{8} \mathrm{MIM}\right]\left[\mathrm{BF}_{4}\right],\left[\mathrm{C}_{4} \mathrm{MIM}\right]$ $\left[\mathrm{PF}_{6}\right]$, and $\left[\mathrm{C}_{6} \mathrm{MIM}\right]\left[\mathrm{PF}_{6}\right]$ [86]. Wang et al. [87] systematically studied the extraction of diverse amino acids (L-tryptophan, L-phenylalanine, L-tyrosine, L-leucine and Dvaline) with the ILs $\left[\mathrm{C}_{6} \mathrm{MIM}\right]\left[\mathrm{BF}_{4}\right],\left[\mathrm{C}_{8} \mathrm{MIM}\right]\left[\mathrm{BF}_{4}\right]$, $\left[\mathrm{C}_{4} \mathrm{MIM}\right]\left[\mathrm{PF}_{6}\right],\left[\mathrm{C}_{6} \mathrm{MIM}\right]\left[\mathrm{PF}_{6}\right]$. Results showed that adjusting the hydrophobicity of the amino acids by changing the $\mathrm{pH}$ value or adding crown ether to the system allowed the target amino acids to be extracted into hydrophobic ILs, which opens the door to the analysis of amino acids in both aqueous phases and biological samples.

\section{Extraction of biomacromolecules}

High-purity nucleic acids, free from a broad range of impurities such as proteins, organic solvents and polysaccharides, are in great demand for DNA sequence analysis, genetic recombination, clinical hybridization, and cloning purposes. The separation and purification of DNA from real sample matrices is of great value, and the utilization of ILs may simplify this separation and purification process [88]. Without any other reagent, ds-DNA was rapidly and quantitatively extracted into $\left[\mathrm{C}_{4} \mathrm{MIM}\right]\left[\mathrm{PF}_{6}\right]$ from the aqueous phase, while part of the extracted DNA can be backextracted to phosphate-citrate buffer. This extraction is selective and has no interference from proteins and metal species. ${ }^{31}$ PNMR and FT-IR spectra studies indicated that the extraction mechanism involves interactions between the cationic $[\mathrm{BMIM}]^{+}$and the $\mathrm{P}-\mathrm{O}$ bonds of phosphate groups in the DNA strands, which take place in both the aqueous phase and at the water/IL interface. The results inferred that this method can function as a sample preparation method for both DNA quantification and DNA purification.

Besides the extraction of DNA into ILs, some DNAbased ILs were also prepared by fixing 1-alkyl-3-methylimidazolium $\left(\mathrm{C}_{\mathrm{n}} \mathrm{MIM}\right)$ cations onto the phosphate groups of DNA [89], and using duplex DNA as the anion and transition metal complexes as cations [90]. These DNAbased ILs have the potential to be used as solvents/reagents for sample preparation because of their unique properties.

The relatively low abundance of some types of proteins and the complicated matrices of biological samples hinder the quantification and structural determination of target proteins. Utilizing the electrical potential between the phases and the salting-out effect induced by the $\left[\mathrm{C}_{4} \mathrm{MIM}\right]$ $\mathrm{Cl} / \mathrm{K}_{2} \mathrm{HPO}_{4}$ aqueous two-phase system, the negatively charged protein BSA in urine samples was extracted into the upper phase with an enrichment factor of about 20 and 
quantified by the Bradford method [91]. UV/Vis and FTIR indicated no structural alterations when BSA was extracted into the $\left[\mathrm{C}_{4} \mathrm{MIM}\right] \mathrm{Cl}$-rich upper phase, which is very important in protein identification. Besides BSA, other proteins such as cytochrome $c(\mathrm{Cyt}-c)$ were also extracted from the aqueous phase into a series of $\mathrm{Tf}_{2} \mathrm{~N}^{-}$-based ILs mediated by dicyclohexano-18-crown-6 (DCH18C6) [92, 93]. Task-specific ILs [18C6MIM][PF6] were also dissolved in traditional ILs to extract this protein [94].

\section{Extraction of nanomaterials}

The wide application of engineered nanomaterials will inevitably result in their introduction into the environment. Accurate assessments of their environmental risks depend on the accurate quantification of nanomaterials in environmental and biological samples. Currently available methods for this quantification are all based on elemental analysis technologies such as ICP-MS [95, 96] and ICP-OES [97]. These methods do offer some information about the existence of nanomaterials, but this information is not conclusive enough, at least for biologically abundand elements such as iron, carbon, selenium. New methods are needed to extract nanomaterials from biological samples and other matrices for further analysis.

Wei et al. [98, 99] demonstrated the feasibility of extracting nanomaterials (gold nanoparticles and gold nanorods, nano-sized $\mathrm{CuO}$ and $\mathrm{Cu}$ ) from the aqueous phase to $\left[\mathrm{C}_{4} \mathrm{MIM}\right]\left[\mathrm{PF}_{6}\right]$ without the need for capping reagents such as thiols. A partitioning process and salt effects were proposed for this extraction. Later, CdTe nanocrystals were also extracted into $\left[\mathrm{C}_{4} \mathrm{MIM}\right]\left[\mathrm{Tf}_{2} \mathrm{~N}\right][100]$. The authors attributed this extraction to a cation-exchange process at the water-IL interface, and they estimated that the distribution ratio is larger than $10^{4}$. ILs may open the door to the analysis of nanomaterials in complicated matrices.

\section{Use of ILs as dissolution solvents}

As ILs can dissolve many compounds, they have been introduced as solvents or matrices for headspace gas chromatography, MALDI-MS analysis, NMR analysis, and other spectral analyses.

\section{For headspace gas chromatography}

Besides extraction, ILs were demonstrated to be advantageous solvents for headspace GC analysis of compounds with low vapor pressures, owing to the nonvolatility and heat stability of ILs [101]. Three acidic, neutral, and basic model analytes with boiling points above $200{ }^{\circ} \mathrm{C}$ dissolved in ILs were determined with limits of detection and limits of quantification at the low-ppm level. This study demonstrated that by properly selecting ILs, it is possible to analyze neutral, acidic, and basic analytes with high boiling points by GC. This method is applicable to the trace analysis of high boiling point, low vapor pressure residual solvents in pharmaceutical drug products. Further, by using $\left[\mathrm{C}_{4} \mathrm{MIM}\right] \mathrm{BF}_{4}$ as the matrix medium, residual solvents with low vapor pressures, such as N-methyl-2-pyrrolidone (NMP) and dimethylformamide (DMF) in Adefovir Dipivoxil (pharmaceutical preparations), were determined with static headspace GC [102].

\section{For MALDI-MS analysis}

Matrix-assisted laser desorption/ionization coupled with mass spectrometry (MALDI-MS) is a powerful technique for determining high molecular weight compounds, especially biomacromolecules. An effective matrix for MALDI should: (i) dissolve (liquid matrix) or cocrystallize (solid matrix) with the sample; (ii) contain a chromophore to absorb laser light and promote ionization of the analyte; (iii) remain in the condensed phase under high-vacuum conditions; and (iv) stifle both chemical and thermal degradation of the sample. ILs satisfy most of these requirments, but their ability to promote ionization is analyte-dependent. The application of ILs as matrices for MADLI-MS analysis has been reviewed recently [103]. In this review, we only provide a few examples of ILs used in sample preparation for MALDI-MS analysis.

Armstrong et al. [104] first tested the possibility of using ILs as matrices for MALDI-MS. They found that by using an $\alpha$-cyano-4-hydroxycinnamic acid (CHCA) anion and triamine-based IL as a reagent to dissolve/cocrystallize peptides, proteins, and poly(ethylene glycol) (PEG-2000), the ion peak intensities and the detection limits obtained with MALDI-MS analysis performed in positive mode $\left(\mathrm{M}+\mathrm{H}^{+}\right)$were comparable or even better than those obtained with the solid matrix CHCA. They also revealed that only those ILs that tend to donate free $\mathrm{H}^{+}$are effective candidates for use as matrices for MALDI-MS, whereas most conventional ILs that lack this property are ineffective as MALDI matrices, at least in the positive mode.

Using 2,5-dihydroxybenzoic acid pyridinium or ammonium as the matrix and phosphoric acid as the matrix additive, MALDI-MS was employed in order to analyze phosphopeptides. In this case, the measurement quality was greatly improved because of the good homogeneity, and the performance of automated measurements was facilitated [105]. Another report showed that by using $\alpha$-cyano-4hydroxycinnamic acid (CCA) pyridinium as matrix and CCA itself as a matrix additive for the identification of proteins by peptide mass-fingerprint analysis with MALDIMS, reduced formation of alkali adducts and matrix 
clusters, which are crucial for protein identification, were observed [106]. The 2,5-dihydroxybenzoic acid butyl amine was also used as a matrix for the analysis of biomolecules and for directly screening enzymatic reactions by MADLI-MS [107]. $\alpha$-Cyano-4-hydroxycinnamic acid (HCCA), 3,5-dihydroxybenzoic acid (DHB) and pyridinebased ILs were also employed in a global metabolite analysis of a 30-metabolite synthetic cocktail which was spiked quantitatively into a microbial extract [108]. By using CCA and indoleacrylic acid (InAA)-based IL as matrices, peptide was quantified without internal standards using MALDI-MS for the monitoring of protease-catalyzed reactions [109].

Besides proteins and peptides, ILs were also used as matrices for the MALDI-MS analysis of other molecules, such as amino acids, oligonucleotides [110, 111], carbonaceous compounds [112], dermatan sulfate and chondroitin sulfate oligosaccharides [113], uncomplexed highly sulfated oligosaccharides [114, 115], aflatoxins [116], chlorosulfolipids [117], and phospholipids [118, 119]. Generally speaking, these ILs have different advantages over a traditional matrix. The most efficient ILs have been demonstrated to be those based on SA, DHB and CCA anions and trialkylamine, amine, methyl- imidazole and pyridium cations.

As they do not satisfy the requirements for the matrix used in MALDI-MS, a large number of ILs that exhibit excellent properties in many applications were excluded from use as the matrix in MALDI-MS. For example, MALDI-MS might be a powerful tool for monitoring the reactions or analyzing the reaction products of many biocatalytic reactions that take place in ILs [120, 121], but the ILs employed in these reactions do not qualify as MALDI-MS matrices. Using laser desorption/ionization (LDI) and MALDI-MS, Masoud et al. [122] characterized five ILs often used in biocatalytic reactions, including $\left[\mathrm{C}_{4} \mathrm{MIM}\right]\left[\mathrm{PF}_{6}\right],\left[\mathrm{C}_{4} \mathrm{MIM}\right]\left[\mathrm{OctSO}_{4}\right]$ (1-butyl-3-methylimidazolium octylsulfate), $\left[\mathrm{C}_{4} \mathrm{MIM}\right]\left[\mathrm{BF}_{4}\right],\left[\mathrm{C}_{4} \mathrm{MIM}\right]\left[\mathrm{Tf}_{2} \mathrm{~N}\right]$ and $\left[\mathrm{C}_{1} \mathrm{MIM}\right]\left[\left(\mathrm{CH}_{3}\right)_{2} \mathrm{PO}_{4}\right]$, and studied their application to the analysis of amino acids, peptides and proteins dissolved in these solvents in the presence of other matrix substances such as SA, DHB and CCA. Although sample homogeneity was sacrificed to some extent, the results were still acceptable, and sodium and potassium adducts were suppressed.

For spectral analysis

As the halogen ions and cyanogen ions in ILs are capable of breaking down the extensive hydrogen bonding network of cellulose, $\left[\mathrm{C}_{4} \mathrm{MIM}\right] \mathrm{Cl}$ and other halogen-containing ILs are able to dissolve cellulose and wood [123, 124]. These discoveries imply that ILs could be used in the analysis of natural marcomolecules that are insoluble in ordinary solvents. To study the ripening of bananas, banana pulp was dissolved in $\left[\mathrm{C}_{4} \mathrm{MIM}\right] \mathrm{Cl}$, and the relative contents of fructose, glucose, sucrose, and amylopectin (the indicator of the ripening stage of the fruit) were analyzed directly using high-resolution ${ }^{13} \mathrm{C}$ NMR spectroscopy [125]. A high-resolution ${ }^{13} \mathrm{C}$ NMR spectroscopic technique was also developed to study the mechanism of cellulose dissolution by $\left[\mathrm{C}_{4} \mathrm{MIM}\right] \mathrm{Cl}$, as well as the conformational behavior of polysaccharide upon solvation by ILs [126]. The NMR approach appeared to be sensitive, universal, noninvasive, and additive-free. Therefore, reactions taking place in ILs can be analyzed in situ without the need for any other sample preparation process.

Enantiomeric recognition and determination, especially for pharmaceutical products, is always of great importance. Some chiral ILs could be used as both solvents and chiral selectors for this purpose. Pharmaceutical products were dissolved in $(R)$ - and $(S)$-[(3-chloro-2-hydroxypropyl) trimethylammonium][bis((trifluoromethyl)- sulfonyl)amide] and analyzed by NIR. Results showed that, due to the high solubility of the analytes in ILs and the strong induced diastereomeric interactions between the analytes and ILs, this method is very sensitive and accurate. Due to its relatively short analysis time and simple procedure, this method could find wide application and universal utility in the analysis of various compounds [127]. The same ILs were also used to determine the enantiomeric purities of propranolol, naproxen, and warfarin by fluorescence spectroscopy [128].

\section{Problems and challenges}

\section{IL impurity}

ILs are relatively impure, which limits their application to sample preparation. Many synthetic methodologies lead to ILs with yellowish or even brown colors, especially when 1-alkyl-3-methylimidazolium halides are used as starting materials to synthesize other ILs [129]. The impurities that cause this discoloration are reported to be below the detection limit of NMR spectroscopy, but they give ILs strong nonessential UV-Vis absorption and wide fluorescence emission, which interferes with absorbance measurements after sample preparation. Because of the unique properties of ILs, the most commonly used purification methods, such as distillation, are ineffective (with a few exceptions) [130]. Fortunately, some purified ILs can be obtained using strategies such as column chromatography [129-131].

IL (in)stability

As most ILs consist of halogen-containing anions such as $\left[\mathrm{AlCl}_{4}\right]^{-},\left[\mathrm{PF}_{6}\right]^{-},\left[\mathrm{BF}_{4}\right]^{-},\left[\mathrm{CF}_{3} \mathrm{SO}_{3}\right]^{-}$, and $\left[\mathrm{Tf}_{2} \mathrm{~N}\right]^{-}$, their 
stabilities are a concern. The presence of water in most samples could cause the hydrolysis of labile anions such as $\left[\mathrm{AlCl}_{4}\right]^{-}$and $\left[\mathrm{PF}_{6}\right]^{-}$. The use of heating, ultrasonication and microwaves in sample preparation may also result in the decomposition of ILs.

$\mathrm{HF}$ and $\left[\mathrm{C}_{4} \mathrm{MIM}\right] \mathrm{F} \cdot \mathrm{H}_{2} \mathrm{O}$ were identified by Swatloski [132] as decomposition products from the hydrolytic degradation of $\left[\mathrm{C}_{4} \mathrm{MIM}\right]\left[\mathrm{PF}_{6}\right]$ during its preparation and drying. Researchers studied the thermal stability of cyanocontaining ILs and found that four of the tested ILs underwent a decomposition process at $100{ }^{\circ} \mathrm{C}$ for one week [133]. Decomposition of the IL was also observed when voltage differences larger than their electrochemical windows (4-6 V) were applied [134]. The instability of ILs and their decomposition products may have negative effects on the target analyte and interfere with the analysis.

Changing the structures/conformations of analytes

Although a number of works have reported enzyme catalysis in ILs, which implies that the structure and activity of the enzyme/protein are maintained in the IL [135], some ILs are also known to alter the structure and activity of biomacromolecules.

Cellulose from Trichoderma reesei was irreversibly denatured in ILs as a result of a salt-induced structural change (unfolding) of cellulose [136]. Candida antarctica Lipase B (CALB), which formed a seemingly homogeneous solution in water, was found to form aggregates in 1ethyl-3-methylimidazolium dicyanamide $\left(\left[\mathrm{C}_{2} \mathrm{MIM}\right][\mathrm{N}\right.$ $\left.\left.(\mathrm{CN})_{2}\right]\right)[137]$. The activity of CYP3A4 in the ILs [CMIM] [BF4], $\left[\mathrm{C}_{4} \mathrm{MIM}\right][\mathrm{BF} 4]$ and $\left[\mathrm{C}_{4} \mathrm{Pyr}\right][\mathrm{BF} 4]$ dropped to $\leq$ $20 \%$ [138]. As a result of the interactions between the cation 1-butyl-3-methylimidazolium $\left[\mathrm{C}_{4} \mathrm{MIM}\right]^{+}$and the $\mathrm{P}-\mathrm{O}$ bonds of phosphate groups in DNA strands, the DNA conformations were modified [105]. These changes in structure and activity may affect the quantification of biomolecules after sample preparation.

\section{IL toxicity}

Although ILs are considered green solvents, mainly due to their lack of vapor pressure, ILs show high hydrophilicity, with $K_{\text {ow }}<5$ [139], and may be introduced into the environment through water. Recently, researchers have become more and more concerned about the toxicity of ILs [140]. Pretti et al. [141] evaluated the acute toxicity and histological damage derived from exposure of Danio rerio (zebrafish) to several ILs (including imidazolium, pyridinium, pyrrolidinium and ammonium-based ILs). The results show that the $\mathrm{LC}_{50}(96 \mathrm{~h})$ values of the most commonly tested ILs (13 out of 15) were greater than $100 \mathrm{mg} / \mathrm{l}$, which is non-highly lethal towards zebrafish, while two of them
(AMMOENG 100 and AMMOENG 130) showed $\mathrm{LC}_{50}$ values that were significantly lower than the organic solvents and tertiary amines. Docherty [142] and coauthors assessed the mutagenicity of some ILs by Ames test. Their results indicated that some ILs present a risk of causing missense mutations, but only at the highest doses. Using quantitative structure-property relationship modeling, the cytotoxicities or toxicities of ILs and the factors responsible for their toxicity were evaluated. Anions as well as cations of ILs were blamed for the toxicity of ILs [143-148].

Acknowledgements This work is supported by the National Natural Science Foundation of China (20621703, 20577059).

\section{References}

1. Suarez PAZ, Einloft S, Dullius JEL, de Souza RF, Dupont J (1998) J Chim Phys 95:1626-1639

2. Huddleston JG, Visser AE, Reichert WM, Willauer HD, Broker GA, Rogers RD (2001) Green Chem 3:156-164

3. Welton T (1999) Chem Rev 99:2071-2033

4. Wilkes JS (2002) Green Chem 4:73-80

5. Wilkes JS, Levisky JA, Wilson RA, Hussey CL (1982) Inorg Chem 21:1263-1264

6. Wilkes JS, Zaworotko MJ (1992) J Chem Soc Chem Commun 13:965-967

7. Dupont J, de Souza RF, Suarez PAZ (2002) Chem Rev 102:3667-3692

8. Freemantle M (1998) Chem Eng News 76:32

9. Armstrong DW, He L, Liu YS (1999) Anal Chem 71:3873-3876

10. Anderson JL, Armstrong DW (2003) Anal Chem 75:4851-4858

11. Qi M, Armstrong DW (2007) Anal Bioanal Chem 388:889-899

12. Yanes EG, Gratz SR, Baldwin MJ, Robison SE, Stalcup AM (2001) Anal Chem 73:3838-3844

13. Vaher M, Koel M, Kaljurand M (2002) Electrophoresis 23:426430

14. Mwongela SM, Numan A, Gill NL, Agbaria RA, Warner IM (2003) Anal Chem 75:6089-6096

15. Borissova M, Gorbatsova J, Ebber A, Kaljurand M, Koel M, Vaher M (2007) Electrophoresis 28:3600-3605

16. Armstrong DW, Zhang LK, He L, Gross ML (2001) Anal Chem 73:3679-3686

17. Carda-Broch S, Berthod A, Armstrong DW (2003) Rapid Commun Mass Spectrom 17:553-560

18. Li YL, Gross ML (2004) J Am Soc Mass Spectrom 15:18331837

19. Tran CD, Yu S (2005) J Colloid Interf Sci 288:613-618

20. Giernoth R, Bankmann D, Schlorer N (2005) Green Chem 7:279-282

21. Fort DA, Swatloski RP, Moyna P, Rogers RD, Moyna G (2006) Chem Commun 714-716

22. Nishi N, Imakura S, Kakiuchi T (2006) Anal Chem 78:27262731

23. Liu JF, JA Jonsson, Jiang GB (2005) Trend Anal Chem 24:20-27

24. Armstrong DW, Anderson JL, Wei GZ (2006) Anal Chem 78:2893-2902

25. Pandey S (2006) Anal Chim Acta 556:38-45

26. Shamsi SA, Danielson ND (2007) J Sep Sci 30:1729-1750

27. Han XX, Armstrong DW (2007) Acc Chem Res 40:1079-1086

28. Chen Y, Guo ZP, Wang XY, Qiu CG (2008) J Chromatogr A 1184:191-219 
29. Huddleston JG, Willauer HD, Swatloski RDP, Visser AE, Rogers RD (1998) Chem Commun 1765-1766

30. Carda-Broch S, Berthod A, Armstrong DW (2003) Anal Bioanal Chem 375:191-199

31. Dai S, Ju YH, Barnes CE (1999) J Chem Soc Dalton Trans 1201-1202

32. Dietz ML, Dzielawa JA (2001) Chem Commun 2124-2125

33. Visser AE, Jensen MP, Laszak I, Nash KL, Choppin GR, Rogers RD (2003) Inorg Chem 42:2197-2199

34. Jensen MP, Dzielawa JA, Rickert P, Dietz ML (2002) J Am Chem Soc 124:10664-10665

35. Jensen MP, Neuefeind J, Beitz JV, Skanthakumar S, Soderholm L (2003) J Am Chem Soc 125:15466-15473

36. Li CP, Xin BP, Xu WG, Zhang QS (2007) J Chem Technol Biotechnol 82:196-204

37. Cocalia VA, Holbrey JD, Gutowski KE, Bridges NJ, Rogers RD (2006) Tsinghua Sci Tech 11:188-193

38. Liu JF, Jiang GB, Chi YG, Cai YQ, Zhou QX, Hu JT (2003) Anal Chem 75:5870-5876

39. Vidal L, Sillakis EP, Domini CE, Grane N, Marken F, Canals A (2007) Anal Chim Acta 584:189-195

40. Ye CL, Zhou QX, Wang XM, Xiao JP (2007) J Sep Sci 30:42-47

41. Liu JF, Chi YG, Jiang GB, Tai C, Peng JF, Hu JT (2004) J Chromatogr A 1026:143-147

42. Ye CL, Zhou QX, Wang XM (2006) Anal Chim Acta 572:165-171

43. Liu JF, Chi YG, Jiang GB (2005) J Sep Sci 28:87-91

44. Peng JF, Liu JF, Jiang GB, Tai C, Huang MJ (2005) J Chromatogr A 1072:3-6

45. Zhou Q, Bai H, Xie G, Xiao G (2008) J Chromatogr A 1177:4349

46. Ohno H, Fukomoto K (2007) Acc Chem Res 40:1122-1129

47. Fukumoto K, Ohno H (2007) Angew Chem Int Ed 46:18521855

48. Liu JF, Li N, Jiang GB, Liu JM, JA Jonsson, Wen MJ (2005) J Chromatogr A 1066:27-32

49. Hsieh YN, Huang PC, Sun IW, Whang TJ, Hsu CY, Huang HH, Kuei CH (2006) Anal Chim Acta 557:321-328

50. Li JD, Cai YQ, Shi YL, Mou SF, Jiang GB (2008) Talanta 74:498-504

51. Aguilera-Heirador E, Lucena R, Cardenas S, Valcarcel M (2008) Anal Chem 80:793-800

52. Khodaoust AP, Chandrasekaran S, Dionysiou D (2006) Environ Sci Technol 40:2339-2345

53. Zhao WY, Han M, Dai SG, Xu J, Wang P (2006) Chemosphere 62:1623-1629

54. Luo HM, Dai S, Bonnesen PV (2004) Anal Chem 76:2773-2779

55. Heitzman H, Young BA, Rausch DJ, Rickert P, Stepinski DC, Dietz ML (2006) Talanta 69:527-531

56. Sieffert N, Wipff G (2006) J Phys Chem A 110:1106-1117

57. Visser AE, Swatloski RP, Reichert WM, Griffin ST, Rogers RD (2000) Ind Eng Chem Res 39:3596-3604

58. Luo HM, Dai S, Bonnesen PV, Buchanan AC, Holbrey JD, Bridges NJ, Rogers RD (2004) Anal Chem 76:3078-3083

59. Sun XQ, Peng B, Chen J, Li DQ, Luo F (2008) Talanta 74:10711074

60. Mekki S, Wai CM, Billard I, Moutiers G, Burt J, Yoon B, Wang JS, Gaillard C, Ouadi A, Hesemann P (2006) Chem Eur J 12:1760-1766

61. Wei GT, Yang ZS, Chen CJ (2003) Anal Chim Acta 488:183192

62. Papaiconomou N, Lee JM, Salminen J, von Stosch M, Prausnitz JM (2008) Ind Eng Chem Res 47(15):5080-5086

63. Shimojo K, Goto M (2004) Anal Chem 76:5039-5044

64. Shan HX, Li ZJ, Li M (2007) Microchim Acta 159:95-100

65. Li ZJ, Wei Q, Yuan R, Zhou X, Liu HZ, Shan HX, Song QJ (2007) Talanta 71:68-72
66. Li ZJ, Lu NP, Zhou X, Song QJ (2007) J Pharmaceut Biomed 43:1609-1614

67. Visser AE, Swatloski RP, Reichert WM, Mayton R, Sheff S, Wierzbicki A, Davis JH, Rogers RD (2001) Chem Commun 135-136

68. Visser AE, Swatloski RP, Reichert WM, Mayton R, Sheff S, Wierzbicki A, Davis JH, Rogers RD (2002) Environ Sci Technol 36:2523-2529

69. Ouadi A, Gadenne B, Hesemann P, Moreau JJE, Billard I, Gaillard C, Mekki S, Moutiers G (2006) Chem Eur J 12:30743081

70. Ouadi A, Klimchuk O, Gaillard C, Billard I (2007) Green Chem 9:1160-1162

71. Germani R, Mancini MV, Savellia G, Spreti N (2007) Tetrahedron Lett 48:1767-1769

72. Vidal L, Chisvert A, Canals A, Salvador A (2007) J Chromatogr A 1174:95-103

73. He CY, Li SH, Liu HW, Li KA, Liu F (2005) J Chromatogr A 1082:143-149

74. Lei ZG, Chen BH, Li CY (2007) Chem Eng Sci 62:3940-3950

75. Yang P, Lau CW, Liu X, Lu JZ (2007) Anal Chem 79:84768485

76. Li SH, He CY, Liu HW, Li KA, Liu F (2005) J Chromatogr B 826:58-62

77. Liu JF, Peng JF, Chi YG, Jiang GB (2005) Talanta 65:705-709

78. Cieniecka- Rosłonkiewicz A, Sas A, Przybysz E, Morytz B, Syguda A, Pernak J (2007) Chem Biodivers 4:2218-2224

79. Cull SG, Holbrey JD, Vargas-Mora V, Seddon KR, Lye GJ (2000) Biotechnol Bioeng 69:227-233

80. Matsumoto M, Ohtani T, Kondo K (2007) J Membrane Sci 289:92-96

81. Richardson SD (2002) Trend Anal Chem 22:666-684

82. Richardson SD (2002) Anal Chem 74:2719-2742

83. Richardson SD (2003) Anal Chem 75:2831-2857

84. Richardson SD (2004) Anal Chem 76:3337-3364

85. Smirnova SV, Torocheshnikova II, Formanovsky AA, Pletnev IV (2004) Anal Bioanal Chem 378:1369-1375

86. Wang JJ, Pei YC, Zhao Y, Zhang SJ (2005) Chinese J Chem 23:662-664

87. Wang JJ, Pei YC, Zhao Y, Hu ZG (2005) Green Chem 7:196202

88. Wang JH, Cheng DH, Chen XW, Du Z, Fang ZL (2007) Anal Chem 79:620-625

89. Nishimura N, Nomura Y, Nakamura N, Ohno H (2005) Biomaterials 26:5558-5563

90. Leone AM, Weatherly SC, Williams ME, Thorp HH, Murray RW (2001) J Am Chem Soc 123:218-222

91. Du Z, Yu YL, Wang JH (2007) Chem Eur J 13:2130-2213

92. Shimojo K, Nakashima K, Kamiya N, Goto M (2006) Biomacromolecules 7:2-5

93. Shimojo K, Kamiya N, Tani F, Naganawa H, Naruta Y, Goto M (2006) Anal Chem 78:7735-7742

94. Kubota F, Koyanagi Y, Nakashima K, Shimojo K, Kamiya N, Goto M (2007) Solvent Extr Res Dev 14:115-120

95. De Jong WH, Hagens WI, Krystek P, Burger MC, Sips AJ, Geertsma RE (2008) Biomaterials 29:1912-1919

96. Yang RSH, Chang LW, Wu JP, Tsai MH, Wang HJ, Kuo YC, Yeh TK, Yang CS, Lin PP (2007) Environ Health Persp 115:1339-1343

97. Ryan JA, Overton KW, Speight ME, Oldenburg CN, Loo LN, Robarge W, Franze S, Feldheim DL (2007) Anal Chem 79:9150-9159

98. Wei GT, Yang Z, Lee CY, Yang HY, Wang CRC (2004) J Am Chem Soc 126:5036-5037

99. Huang HL, Wang HP, Wei GZ, Sun IW, Huang JF, Yang YW (2006) Environ Sci Technol 40:4761-4764 
100. Nakashima T, Kawai T (2005) Chem Commun 1643-1645

101. Andre M, Loidl J, Laus G, Schottenberger H, Bentivoglio G, Wurst K, Ongania KH (2005) Anal Chem 77:702-705

102. Liu FH, Jiang Y (2007) J Chromatogr A 1167:116-119

103. Tholey A, Heinzle E (2006) Anal Bioanal Chem 386:24-37

104. Armstrong DW, Zhang LK He LF, Gross ML (2001) Anal Chem 73:3679-3686

105. Tholey A (2006) Rapid Commun Mass Spectrom 20:1761-1768

106. Moghaddam MZ, Heinzle E, Lasaosa M, Tholey A (2006) Anal Bioanal Chem 384:215-224

107. Mank B, Stahl B, Boehm G (2004) Anal Chem 76:2938-2950

108. Vaidyanathan S, Gaskell S, Goodacre R (2006) Rapid Commun Mass Spectrom 20:1192-1198

109. Tholey A, Moghaddam MZ, Heinzle E (2006) Anal Chem 78:291-297

110. Broch SC, Berthod A, Armstrong DW (2003) Rapid Commun Mass Spectrom 17:553-560

111. Li YL, Gross ML (2004) J Am Soc Mass Spectrom 15:18331837

112. Hurtado P, Hortal AR, Haya BM (2007) Rapid Commun Mass Spectrom 21:3161-3164

113. Laremore TN, Zhang FM, Linhard RJ (2007) Anal Chem 79:1604-1610

114. Laremore TN, Murugesan S, Park TJ, Avci FY, Zagorevski DV, Linhardt RJ (2006) Anal Chem 78:1774-1779

115. Catharino RD, Marques LA, Santos LA, Baptista BS, Gloria EM, Calori-Domingues MA, Facco EMP, Eberlin MN (2005) Anal Chem 77:8155-8157

116. Darsow KH, Lange HA, Resch M, Walter C, Buchholz R (2007) Rapid Commun Mass Spectrom 21:2188-2194

117. Jones JJ, Batoy SM, Wilkins CL (2005) J Am Soc Mass Spectrom 16:2000-2008

118. Li YL, Gross ML (2005) J Am Soc Mass Spectrom 16:679-682

119. Cull SG, Holbrey JD, Vargas-Mora V, Seddon KR, Lye GJ (2000) Biotechnol Bioeng 69:227-233

120. Pfruender H, Amidjojo M, Kragl U, Weuster-Botz D (2004) Angew Chem Int Ed 43:4529-4531

121. Tholey A, Zabet-Moghaddam M, Heinzle E (2006) Anal Chem 78:291-297

122. Swatloski RP, Spear SK, Holbrey JD, Rogers RD (2002) J Am Chem Soc 124:4974-4975

123. Kikpelainen I, Xie HB, King A, Granstrom M, Heikkinen S, Argyropoulos DS (2007) J Agric Food Chem 55:9142-9148

124. Fort DA, Swatloski RP, Moyna P, Rogers RD, Moyna G (2006) Chem Commun 714-716
125. Moulthrop JS, Swatloski RP, Moyna G, Rogers RD (2005) Chem Commun 1557-1559

126. Tran CD, Oliveira D, Yu SF (2006) Anal Chem 78:1349-1356

127. Tran CD, Oliveira D (2006) Anal Biochem 356:51-58

128. Nockemann P, Binnemans K, Driesen K (2005) Chem Phys Lett 415:131-136

129. Earle MJ, Esperanca JMSS, Gilea MA, Lopes JNC, Rebelo LPN, Magee JW, Seddon KR, Widegren JA (2006) Nature 439:831-834

130. Earle MJ, Gordon CM, Plechkova NV, Seddon KR, Welton T (2007) Anal Chem 79:758-764

131. Swatloski RP, Holbrey JD, Rogers RD (2003) Green Chem 5:296-299

132. Wooster TJ, Johanson KM, Fraser KJ, MacFarlane DR, Scott JL (2006) Green Chem 8:691-696

133. Kroon MC, Buijs W, Peters CJ, Witkamp GJ (2006) Green Chem 8:241-245

134. Kragl U, Eckstein M, Kaftzik N (2002) Curr Opin Biotech 13:565-571

135. Turner MB, Spear SK, Huddleston JG, Holbrey JD Rogers RD (2003) Green Chem 5:443-447

136. Sate D, Janssen MH, Stephens G, Sheldon RA, Seddon KR, Lu JR (2007) Green Chem 9:859-867

137. Chefson A, Auclair K (2007) Chem Bio Chem 8:1189-1197

138. Pernak J, Sobaszkiewicz K, Mirsk I (2003) Green Chem 5:52-56

139. Ropel L, Belveze LS, Aki SNVK, Stadtherr MA, Brennecke JF (2005) Green Chem 7:83-90

140. Pretti C, Chiappe C, Pieraccini D, Gregori M, Abramo F, Monni G, Intorre L (2006) Green Chem 8:238-240

141. Docherty KM, Hebbeler SZ, Kulpa CF (2006) Green Chem 8:560-567

142. Stolte S, Arning J, Weber UB, Matzke M, Stock F, Thiele K, Uerdingen M, Biermann UW, Jastorff B, Ranke J (2006) Green Chem 8:621-629

143. Couling DJ, Bernot RJ, Docherty KM, Dixon JK, Maginn MJ (2006) Green Chem 8:82-90

144. Frade RFM, Matias A, Branco LC, Afonso CAM, Duarte CMM (2007) Green Chem 9:873-877

145. Couling DJ, Bernot RJ, Docherty KM, Dixon JK, Maginn EJ (2006) Green Chem 8:82-90

146. Jastorff B, Störmann R, Ranke J, Mölter K, Stock F, Oberheitmann B, Hoffmann W, Hoffmann J, Nüchter M, Ondruschka B, Filser J (2003) Green Chem 5:136-142

147. Frade RFM, Matias A, Branco LC, Afonso CA, Duarte CMM (2007) Green Chem 9:873-877

148. Stetter JR, Li J (2008) Chem Rev 108:352-366 